\title{
Identification of antibodies to Leptospira spp. in the spot-legged turtle (Rhinoclemmys punctularia) maintained in captivity
}

\section{Identificação de anticorpos para Leptospira spp. em aperemas (Rhinoclemmys punctularia) mantidas em cativeiro}

\author{
Katarine de Souza Rocha ${ }^{1}$; Ianny Watuzy Monteiro Baia'²; Louysse Helene \\ Monteiro $^{3}$; Juliana Maria Santos Miranda ${ }^{4}$; Thamillys Rayssa Marques Monteiro ${ }^{5}$; \\ Andréia Ferreira da Silva'; Thalita Amaral dos Reis ${ }^{6}$; Maeli Fernanda Silva \\ Ferreira $^{6}$; Ellen Yasmin Eguchi Mesquita ${ }^{7}$; Carla Cristina Guimarães de Moraes ${ }^{8^{*}}$
}

\begin{abstract}
Leptospirosis is a zoonosis of worldwide distribution in which the agent can infect several animal species and accidentally humans. In view of the limited number of studies on anti-Leptospira antibodies in wild animal species, especially those living in aquatic environments, we sought in this study to investigate the presence of these antibodies in the spot-legged turtle (Rhinoclemmys punctularia) maintained in captivity in the Rodrigues Alves Botanical Garden-Amazon Zoobotanical Park, located in Belém, Pará State, Brazil. Serum samples were collected from 31 turtles, and identification of antiLeptospira antibodies was performed using the microscopic agglutination test, using a collection of 31 live antigens which represent 19 serogroups of Leptospira. Among the analyzed samples, 54.83\% $(17 / 31)$ were observed to be reactive, and co-agglutination was detected in a further six samples which were not accounted for in the frequency of serogroups. The most frequently detected serogroups were Tarassovi $72.72 \%$ (8/11), Celledoni 18.18\% (2/11), and Pomona 9.09\% (1/11)], with titers ranging from 200 to 400 , being this the first study to report infection of these serogroups in this species of chelonios. The animals were kept in water tanks, which probably favored the transport of the agent and allowed its transmission to the spot-legged turtle. We thus confirmed presence of anti-Leptospira antibodies in chelonians maintained in the Rodrigues Alves Botanical Garden.
\end{abstract}

Key words: Leptospirosis. Microscopic agglutination test. Wild animal.

1 Discentes do Programa de Pós-Graduação em Saúde Animal na Amazônia, PPGSAAM, Laboratório de Zoonoses e Saúde Pública, Instituto de Medicina Veterinária, Universidade Federal do Pará, UFPA, Castanhal, PA, Brasil. E-mail: katarinemv@ gmail.com; andreiafsilva2005@yahoo.com.br

2 Médica Veterinária Autônoma, Belém, PA, Brasil. E-mail: ianny j.c@hotmail.com

3 Residente da Comissão Nacional de Residência Multiprofissional em Área da Saúde, Especialidade de Clínica Médica e Cirurgia de Animais Silvestres, Instituto de Medicina Veterinária, UFPA, Castanhal, PA, Brasil. E-mail: helenelouysse@gmail.com

4 Residente da Comissão Nacional de Residência Mutiprofissional em Área da Saúde, Especialidade de Medicina de Animais Selvagens, Setor Ambulatório de Animais Selvagens, UFRA, Belém, PA, Brasil. E-mail: juhmiranda30@gmail.com

5 Residente da Comissão Nacional de Residência Mutiprofissional em Área da Saúde, Especialidade de Medicina Veterinária Preventiva, Instituto de Saúde e Produção Animal, ISPA, UFRA, Belém, PA, Brasil. E-mail: thamymonteiro@hotmail.com

6 Discente, Curso de Medicina Veterinária. Laboratório de Zoonoses e Saúde Pública, Instituto de Medicina Veterinária, UFPA, Castanhal, PA, Brasil. E-mail: thalita areis@hotmail.com; maelifernandasf@gmail.com

7 Médica Veterinária do Bosque Rodrigues Alves, Prof ${ }^{a}$, Universidade da Amazônia, UNAMA, Belém, PA, Brasil. E-mail: elleneguchi@yahoo.com.br

8 Prof $^{a}$ Responsável, Laboratório de Zoonoses e Saúde Pública, Instituto de Medicina Veterinária, UFPA, Castanhal, PA, Brasil. E-mail: ccmoraes@ufpa.br

Author for correspondence 


\title{
Resumo
}

\begin{abstract}
A leptospirose é uma zoonose de distribuição mundial, na qual o agente pode infectar várias espécies animais e acidentalmente, humanos. Tendo em vista o número limitado de estudos sobre anticorpos anti-Leptospira em espécies de animais silvestres, especialmente aqueles que vivem em ambientes aquáticos, buscou-se neste estudo investigar a presença desses anticorpos em aperemas (Rhinoclemmys punctularia) mantidas em cativeiro no Jardim Botânico Rodrigues Alves - Parque Zoobotânico da Amazônia, localizado em Belém, estado do Pará, Brasil. Amostras de soro foram coletadas de 31 tartarugas e a identificação de anticorpos anti-Leptospira foi realizada pelo teste de aglutinação microscópica, utilizando-se uma coleção de 31 antígenos vivos que representam 19 sorogrupos de Leptospira. Entre as amostras analisadas, observou-se que 54,83\% (17/31) foram reativas, e detectou-se co-aglutinação em mais seis amostras que não foram contabilizadas na frequência de sorogrupos. Os sorogrupos mais frequentemente detectados foram Tarassovi 72,72\% (8/11), Celledoni 18,18\% (2/11) e Pomona 9,09\% (1/11), com títulos variando de 200 a 400, sendo este o primeiro estudo a relatar a detecção de anticorpos anti-Leptospira spp. nesta espécie de quelônio. Os animais eram mantidos em tanques de água, o que provavelmente favoreceu o transporte do agente e permitindo sua transmissão para as aperemas. Assim, confirmou-se a presença de anticorpos anti-Leptospira em quelônios mantidos no Jardim Botânico Rodrigues Alves.
\end{abstract}

Palavras-chave: Leptospirose. Teste de aglutinação microscópica. Animal selvagem.

Rhinoclemmys punctularia (the spot-legged turtle), popularly known as Perema or Aperema, is a semiaquatic chelonian, commonly found in regions of Central and South America (FIGUEIREDO et al., 2010). This species is generally distributed in areas with aquatic systems, such as coastal wetlands, flooded savannahs, primary and secondary forest water bodies, streams, swampy meadows, ponds, and temporary pools (FRETEY et al., 2007; RUEDA-ALMONACID et al., 2007).

Although reptiles are known to be reservoirs of various zoonotic bacteria (EBANI, 2017), the role of poikilothermic animals in the maintenance and dissemination of Leptospira is still poorly understood (LINDTNER-KNIFIC et al., 2013). Few studies have examined the true epidemiological status of chelonians in relation to leptospirosis, particularly those maintained in captivity due to a lack of knowledge regarding the sanitary profile of wild animals.

Leptospirosis is an infectious-contagious disease that has a zoonotic character and frequently occurs in tropical regions (ACHA; SZYFRES, 2003). The bacterial agents are species of Leptospira, which require hydric conditions to facilitate survival and transmission, and can infect humans and domestic and wild animals (DEZZUTTO et al., 2017). Furthermore, as an anthropozoonosis, leptospirosis can affect the zookeeper of captive animals (ACHA; SZYFRES, 2003).

In the case of chelonians, the dissemination of Leptospira can be catastrophic in populations of wild animals, and may even pose the threat of extinction (GRIMM et al., 2015). Oliveira et al. (2016) detected Leptospira spp. in the droppings of Phrynops geoffroanus (Geoffroy's side-necked turtle), which led to the conclusion that the turtles harbor and disseminate these bacteria, thereby potentially contaminating the environment.

Although there has been a gradual increase in the number of serological investigations in chelonians, there have to date been no such studies on $R$. punctularia, which makes it difficult to assess the extent of Leptospira infection in these turtles. Consequently, in the present study, we aimed to evaluate the serologically reactive frequency of Leptospira spp. for $R$. punctularia maintained in the Rodrigues Alves Botanical Garden-Amazon Zoobotanical Park, located in Belém, Pará State, Brazil. 
The research reported herein was authorized by the Brazilian Biodiversity Authorization and Information System (SISBIO) no. 59785-1. The study was carried out at the Rodrigues Alves Botanical Garden-Amazon Zoobotanical Park $\left(1^{\circ} 25^{\prime} 51.8^{\prime \prime} \mathrm{S}, 48^{\circ} 27^{\prime} 28.7^{\prime \prime} \mathrm{W}\right)$, which covers an area of 15 hectares located in an urban district of Belém. It preserves an important diversity of fauna and flora species of the Amazonian ecosystem and is accordingly considered an important institution with regards to Amazon biodiversity conservation (CARDOSO, 2018). Such characteristics make it an important ecotourism location within the municipality.

Due to the cleaning and disinfection procedures of aquatic tanks in which some species of captive chelonians are maintained, including $R$. punctularia, there was a need for identification and handling of the animals, which eventually favored the collection of blood samples.

After adequate and careful physical restraint, blood samples were collected from 31 R. punctularia individuals by puncturing the caudal vertebral vein or occipital sinus using $3-\mathrm{mL}$ syringes and $20 \times$ 5.5 needles. These samples were stored in tubes without anticoagulant and were subsequently sent to the Zoonoses and Public Health Laboratory of the Veterinary Medicine Institute of the Federal University of Pará (VMEI/FUPA), where they were centrifuged at $2000 \mathrm{rpm}$ for 10 minutes for clot retraction and serum separation. The resulting serum samples were then transferred to marked microtubes and subsequently maintained at $-20^{\circ} \mathrm{C}$ until processed.

Identification of antibodies to Leptospira spp. in the serum samples was performed using the microscopic agglutination test, using live antigens representative of 31 serovars belonging to the serogroups Australis, Autumnalis, Ballum, Bataviae, Canicola, Celledoni, Cynopteri, Djasiman, Grippotyphosa, Hebdomadis, icterohaemorrhagiae, Javanica, Panama, Pomona, Pyrogenes, Sejroe, Shermani, Andamana, and Semaranga. The samples showing an antigen-antibody agglutination reaction with a grade of at least $50 \%$ from the cut-off point 1:100 dilution at the screening step and the highest dilution at the titration step, were considered as reactive.

Of the 31 samples collected, 54.83\% (17/31) were reactive for Leptospira spp. with titers ranging from 100 to 400 for one or more of the serogroups. We also detected co-agglutination in six samples that made it impossible to identify the predominant serogroup, and accordingly these sample were not included in the frequency data. Among the reactive samples, the most frequently detected serogroup was Tarassovi $72.72 \%(8 / 11)$, with titers ranging from 200 to 400 , followed by the serogroups Celledoni $18.18 \%$ (2/11) and Pomona [9.09\% (1/11) (Table 1).

Table 1. Distribution of sero-reactive samples in the detection of anti-Leptospira antibodies using the microscopic agglutination test according to the titers of the most frequently detected serogroups in spot-legged turtle (Rhinoclemmys punctularia) maintained in captivity in the Rodrigues Alves Botanical Garden-Amazon Zoobotanical Park.

\begin{tabular}{cccc}
\hline \multirow{2}{*}{ Serogroups } & Frequency $(\%)$ & $\mathbf{2 0 0}$ & Titers \\
\cline { 3 - 4 } & & $(2 / 11)$ & $\mathbf{4 0 0}$ \\
\hline Tarassovi & $72.72 \%(8 / 11)$ & $(1 / 11)$ & $(1 / 11)$ \\
Celledoni & $18.18 \%(2 / 11)$ & $(1 / 11)$ & - \\
Pomona & $9.09 \%(1 / 11)$ & & \\
Total & $\mathbf{1 0 0 \% ( 1 1 / 1 1 )}$ & & \\
\hline
\end{tabular}


Although research on the occurrence of Leptospira spp. in the species studied is still in the early stages, some studies (ANDREWS et al., 1965; DEZZUTTO et al., 2017; GLOSSER et al., 1974; GRIMM et al., 2015; OLIVEIRA et al., 2016) have indicated that chelonians can serve as possible reservoirs of these agents, showing high prevalence rates similar to those detected of the present study.

Our findings regarding the serogroup Tarassovi, which was most frequently detected in the positive reactions recorded in $R$. punctularia, are consistent with the findings reported by Glosser et al. (1974) for Pseudemys scripta elegans inhabiting settling ponds of an untreated sewage disposal system in the United States. Similar reactions have also been reported by Lindtner-Knific et al. (2013) in Emys orbicularis and Trachemys scripta elegans in Slovenia, and by Dezzutto et al. (2017) in Trachemys scripta in three urban lagoons in Italy.

In Brazil, Silva et al. (2009) found that Trachemys dorbigny from urban lakes in the municipality of Pelotas, Southern Brazil, were also reactive for the Tarassovi serogroup; however, the largest number of animals were reactive for the Bataviae serogroup, which contrasts with the results of the present study.

Although the Tarassovi serogroup has human origins (KIKTENKO \& ANANYIN, 1941), it is one of the most frequently detected serogroups in snakes and chelonians, which, according to Esteves et al. (2005), occurs as a consequence ingesting prey infected by the causal agent.

The serogroup with the second highest number of reactions in the present study was Celledoni and we were unable to find any available literature reports of chelonians infected by this serogroup. Accordingly, the present study is probably the first to detect these agglutinins in $R$. punctularia. The serogroup Pomona had the lowest frequency of serum reactants, which has also been reported by Lindtner-Knific et al. (2013) in Testudo graeca from a reptile breeding farm in Slovenia.
When comparing the results of the present study with those of studies previously conducted in Brazil, there are notable discrepancies in the reported infectious serogroups in chelonians, as demonstrated by Oliveira et al. (2016), who fund that serovar Copenhageni from the serogroup Icterohaemorrhagiae was more frequently detected in samples collected from the eastern box turtle (Terrapene carolina carolina). Similarly, Silva et al. (2010) found that pond turtles of the Emydae family maintained in the municipal zoo of Ribeirão Preto, São Paulo State, Brazil, harbored Andamana.

Although we are unable to verify the source of infection observed in $R$ punctularia, we suspect that exposure to the agent possibly occurred via the water contained in the tanks they inhabit, which may have been contaminated by bacteria disseminated by natural reservoirs, such as rodents and other infected animals, that are often attracted by the food remains left in the enclosures (LOPES et al., 2005; MACHADO et al., 2010).

In addition, the zoobotanical park contains a large diversity of flora, including species of trees with massive canopies. These trees can substantially reduce the incidence of sunlight filtering down to some enclosures, including the tanks containing chelonians, and this, in association with rainfall and high temperatures and humidity, may favor the spread of the infectious agent (MACHADO et al., 2010).

On the basis of the findings of this study, we can conclude that the spot-legged turtle (Rhinoclemmys punctularia) maintained in captivity in the Rodrigues Alves Botanical Garden-Amazon Zoobotanical Park are exposed to different serogroups of Leptospira spp. To the best of our knowledge, this is the first study to report the detection of agglutinins of the serogroups Tarassovi, Celledoni, and Pomona in this species of pond turtle. 


\section{Acknowledgements}

We thank the Amazon Zoobotanical Park for assistance in capturing the animals examined in this study and in the collection of biological samples for this work.

\section{Conflict of Interests}

The authors declare that there are no conflicts of interest.

\section{References}

ACHA, P. N.; SZYFRES, B. Zoonosis y enfermedades transmisibles comunes al hombre ya los animales. Washigton: Organización Panamericana de la Salud, 2003. v. 1, 398 p.

ANDREWS, R. D.; REILLY, J. R.; FERRIS, D.; HANSON, L. E. Leptospiral agglutinins in sera from Southern Illinois Herpetofauna. Journal of Wildlife Diseases, University of Illinois at Urbana-Champaign, v. 1, n.4, p. 55-59, 1965. DOI: 10.7589/0090-3558-1.4.55

CARDOSO, S. L. C. Tomada de decisão em Jardim Botânico: Bosque Rodrigues Alves-Jardim Zoobotânico da Amazônia (BRAJZBA). Amazônia, Organizações e Sustentabilidade, Belém, v. 6, n. 2, p. 123-131, 2018. DOI: http://dx.doi.org/10.17800/2238-8893/aos.v6n2jul/ dez2017p123-131

DEZZUTTO, D.; BARBERO, R.; CANALE, L.; ACUTIS, P. L.; BIOLATTI, C.; DOGLIERO, A.; MITZY, M. D.; FRANCONE, P.; COLZANI, A.; BERGAGNA, S.; GENNERO, M. S. Detection of Leptospira spp. in water turtle (Trachemys scripta) living in ponds of urban parks. Veterinary Sciences, Basel, v. 4, n. 4, p. 51-55, 2017. DOI: $10.3390 /$ vetsci4040051

EBANI, V. V. Domestic reptiles as source of zoonotic bacteria: a mini review. Asian Pacific Journal of Tropical Medicine, Haikou, v. 10, n. 8, p. 723-728, 2017. DOI: 10.1016/j.apjtm.2017.07.020

ESTEVES, F. M.; GUERRA-NETO, G.; GIRIO, R. J. S.; SILVA-VERGARA, M. L.; CARVALHO, A. C. F. B. Detecção de anticorpos para Leptospira spp. em animais e funcionários do zoológico municipal de Uberaba, MG. Arquivos do Instituto Biológico, São Paulo, v. 72, n. 3, p. 283-288, 2005.

FIGUEIREDO, M. W. Estrutura populacional, uso de ambientes e crescimento corporal de Rhinoclemmys punctularia punctularia (Daudin, 1801), na Ilha de
Algodoal/ Maiandeua, Maracanã, Pará, Brasil. 2010. Dissertação (Mestrado) - Instituto de Ciências Biológicas, Universidade Federal do Pará, Pará.

FRETEY, J.; BILLES, A.; TIWARI, M. Leatherback, Dermochelys coriacea, nesting along the Atlantic coast of Africa. Chelonian Conservation Biology, v. 6, n. 1, p. 126-129, 2007. DOI: $10.2744 / 1071-8443$

GLOSSER, J. W.; SULZER, C. R.; EBERHARDT, M.; WINKLER, W. G. Cultural and serologic evidence of Leptospira interrogans serotype Tarassovi infection in turtles. Journal of Wildlife. Diseases, Massachusetts, v. 10 , n. 4, p. 429-435, 1974. DOI: 10.7589/0090-355810.4.429

GRIMM, K.; MITCHELL, M. A.; THOMPSON, D.; MADDOX, C. Seroprevalence of Leptospira spp. in Blanding's Turtles (Emydoidea blandingii) from DuPage County, Illinois USA. Journal of Herpetological Medicine and Surgery, Gainesville, v. 25, n. 1-2, p. 2832, 2015. DOI: $10.5818 / 1529-9651-25.1 .28$

KIKTENKO, V.S.; ANANYIN, V. Leptospiroz na daljnem vostoke (leptospirose do Extremo Oriente). Zeitschrift für allgemeine Mikrobiologie, Moscou, n. 12, p. $72-78,1941$.

LINDTNER-KNIFIC， R.; VERGLES-RATAJ， A.; VLAHOVIĆ, K.; ZRIMŠEK, P.; DOVČ, A. Prevalence of antibodies against Leptospira sp. in snakes, lizards and turtles in Slovenia. Acta Veterinaria Scandinavica, Nova York, v. 55, n. 65, p. 1-8, 2013. DOI: 10.1186/17510147-55-65

LOPES, A. L. S.; SILVA, W. B.; PADOVANI, C. R.; LANGONI, H.; MODOLO, J. R. Frequência sorológica antileptospírica em cães: sua correlação com roedores e fatores ambientais, em área territorial urbana. Arquivos do Instituto Biológico, São Paulo, v. 72, n. 3, p. 289-296, 2005.

MACHADO, F. M. E.; COELHO, H. E.; REZENDE, R. S. Plano de ação para o 28 controle da leptospirose no Zoológico Municipal de Uberaba-MG. Bioscience Journal., Uberlândia, v. 26, n. 6, p. 981-989, 2010.

OLIVEIRA, J. P.; KAWANAMI, A. E.; SILVA, A. S. L.; CHUNG, D. G.; WERTHER, K. Detection of Leptospira spp. in wild Phrynops geoffroanus (Geoffroy's sidenecked turtle) in urban environment. Acta Tropica, Basel, v. 164, p. 165-168, 2016. DOI: $10.1016 / j$. actatropica.2016.08.019

RUEDA-ALMONACID, J. V.; CARR, J. L.; MITTERMEIER, R. A.; RODRÍGUEZ-MAHECHA, J. V.; MAST, R. B.; VOGT, R. C.; RHODIN, A. G. J.; OSSAVELÁSQUEZ, J. de LA; RUEDA, J. N.; MITTERMEIER, C. G. Las tortugas y los cocodrilianos 
de los países andinos del trópico. Serie de guías tropicales de campo $N^{o}$ 6. Conservación Internacional. Editorial Panamericana, Formas e Impresos. Bogotá, 2007. 538 p.

SILVA, C. S.; GÍRIO, R. J. S.; GUERRA NETO, G.; BRICH, M.; SANTANA, L. A. S.; AMÂNCIO, F. H.; MARIANI, J. R.; WESSORT, P. M. F. Anticorpos antiLeptospira spp. em animais selvagens do zoológico municipal de Ribeirão Preto, Estado de São Paulo, Brasil.
Brazilian Journal of Veterinary Research and Animal Science, São Paulo, v. 47, n. 3, p. 237-242, 2010. DOI: 10.11606/issn.1678-4456.bjvras.2010.26862

SILVA, E. F.; SEYFFERT, N.; CERQUEIRA, G. M. Serum antileptospiral agglutinins in freshwater turtles from Southern Brazil. Brazilian Journal of Microbiology, São Paulo, v. 40, n. 2, p. 227-230, 2009. DOI: 10.1590/ S1517-83822009000200003 